\title{
Interactions between salmonid serum components and the extracellular haemolytic toxin of Aeromonas salmonicida
}

\author{
K.-K. Lee* , A. E. Ellis** \\ SOAFD Marine Laboratory, PO Box 101, Victoria Road, Aberdeen AB9 8DB, Scotland, United Kingdom
}

\begin{abstract}
The interactions between salmonid serum components and the lethal extracellular haemolytic toxin (glycerophospholipid:cholesterol acyltransferase complexed with lipopolysaccharide. GCAT/LPS) of Aeromonas salmonicida were studied. Low density lipoprotein-like (LDL-like) fractions, high density lipoprotein (HDL) and serum albumin were purified from Atlantic salmon Salmo salar L. serum using Fast Protein Liquid Chromatography - gel filtration and/or anion exchange columns. LDLlike fractions, HDL, and albumin enhanced phospholipase activities of the GCAT/LPS. Rainbow trout Oncorhynchus mykiss serum and salmon LDL-like fractions, HDL, and albumin all inhibited the haemolytic activity of the GCAT/LPS in the short term $(2 \mathrm{~h})$; but after $24 \mathrm{~h}$ incubation, both albumin and trout serum markedly enhanced this activity. In electrophoretic studies, prior incubation with the GCAT/LPS significantly increased the mobility of the LDL-like fractions, HDL, and albumin fractions. These data indicate that the interaction between the fish serum components and the GCAT/LPS results in net activation of phospholipase and haemolytic activities of the toxin and causes disturbances in the properties of the serum albumin and lipoproteins. These complex events may significantly contribute to the pathogenicity of $A$. salmonicida.
\end{abstract}

\section{INTRODUCTION}

In our previous papers (Lee \& Ellis 1989, 1990) a lethal cytolysin, glycerophospholipid:cholesterol acyltransferase complexed with lipopolysaccharide (GCAT/LPS), was purified and characterised. The enzyme is the major lethal toxin in the extracellular products of Aeromonas salmonicida and has haemolytic, leucocytolytic, and cytotoxic activities. In the native state, the enzyme complexed with LPS has a high molecular weight but under denaturing conditions in sodium dodecyl sulphate-polyacrylamide gel electrophoresis (SDS-PAGE) a single protein band with MW $25 \mathrm{kDa}$ is obtained.

The GCAT enzyme shares several properties with the mammalian plasma enzyme lecithin:cholesterol acyltransferase (LCAT), e.g. both enzymes are capable

\footnotetext{
- Present address: Department of Aquaculture, National Taiwan Ocean University, 2 Pei-Ning Road, Keelung, Taiwan, Republic of China

- Addressee for correspondence
}

of catalysing the transfer of a fatty acid from the 2 position of phosphatidylcholine to cholesterol; both act as phospholipases when no acyl acceptor is present; and both act as lysophospholipases (Subbaiah et al. 1980, Buckley 1982, 1983, Buckley et al. 1982, 1984). Although the stimulation of the enzymic activity of GCAT by bovine serum albumin (essentially fatty acid free) and human apolipoprotein A-1 has been described (Buckley et al. 1982), the interactions of GCAT with components of salmonid fish serum have not previously been studied. Since the GCAT/LPS almost certainly plays a crucial role in the disease process, the present study was undertaken to investigate the interactions between this toxin and fish serum components.

\section{MATERIALS AND METHODS}

Experimental fish. Blood was obtained from the caudal vessels of 4 anaesthetised (benzocaine) immature sea water Atlantic salmon Salmo salar L. weighing 200 to $300 \mathrm{~g}$. After clotting at room temperature $\left(20^{\circ} \mathrm{C}\right)$, 
the serum was collected, pooled, and used fresh for fractionation; the remainder was stored at $-20^{\circ} \mathrm{C}$ in $1 \mathrm{ml}$ aliquots. Rainbow trout Oncorhynchus mykiss weighing about $200 \mathrm{~g}$ were used as sources of erythrocytes and serum.

Bacteria and extracellular products. Aeromonas salmonicida MT 004 (URL 2862, Unilever Research Ltd, Bedford, UK), which was originally autoaggregating but now is non-aggregating (A-layer negative), was used to produce extracellular products (ECP) as previously described (Munro et al. 1980). Haemolytic activity was measured by a microtitration method using rainbow trout erythrocytes as described previously (Hastings \& Ellis 1985). Haemolytic titres were read after 2,7 , and $24 \mathrm{~h}$.

Cytolysin (iecithinase). The purified cytolysin, glycerophospholipid:cholesterol acyltransferase/lipopolysaccaride complex (GCAT/LPS), was obtained as previously described (Lee \& Ellis 1990).

Purification of salmon serum proteins. Atlantic salmon serum $(200 \mu \mathrm{l})$ was applied to a Fast Protein Liquid Chromatography (FPLC) Superose 12 gel filtration column (Pharmacia), and eluted with physiological phosphate-buffered saline (PBS), pH 7.2. (Dulbecco's $\mathrm{Ca}^{2+}$ and $\mathrm{Mg}^{2+}$ free, Gibco), at a flow rate of $0.5 \mathrm{ml} \mathrm{min}^{-1}$. One $\mathrm{ml}$ fractions were collected. Some of the fractions were further fractionated in an FPLC anion-exchange column as follows. Samples were diluted 10 -fold with distilled water and applied to a Mono Q HR 5/5 column equilibrated with $20 \mathrm{mM}$ Tris (hydroxymethyl) methylamine $\mathrm{HCl}, \mathrm{pH}$ 7.7. Fractions were eluted with a sodium chloride gradient in equilibration buffer at a rate of $1 \mathrm{ml} \mathrm{min}{ }^{-1}$. One $\mathrm{ml}$ fractions were collected.

Protein lipid, and cholesterol determination. Total protein was measured by the method of Bradford (1976) using bovine serum albumin (fatty acid free, Sigma) as standard.

A total lipid colorimetric method (Boehringer Mannheim $\mathrm{GmbH}$, Germany) was employed according to the manufacturer's instructions for determining the lipid amounts.

Total cholesterols were detected using a kit purchased from Sigma Chemical Company (cholesterol procedure No 352).

Electrophoresis. Phastgels (12.5\% polyacrylamide) were used in the PhastSystem (Pharmacia). Pharmacia low molecular weight calibration kits were used as marker proteins. The procedures were conducted according to the manufacturer's recommendations. After electrophoresis, gels were stained with silver or Coomassie brilliant blue, as recommended by the PhastSystem protocols. Bovine serum albumin (fraction $V$, Sigma) and rabbit serum albumin (fraction $V$, Sigma) were used as standards in the identification of fish serum in native PAGE using an iodine staining technique in which the gels were immersed in saturated iodine solution for $30 \mathrm{~min}$ to $1 \mathrm{~h}$ (Lee \& Ellis 1991a).

Lecithinase and phospholipase assay. Lecithinase activity was detected by placing samples in wells cut in agarose ( $1 \%$ in $0.05 \mathrm{M}$ tris-barbiturate buffer, $\mathrm{pH} 8.6$ ) containing $0.2 \%$ (w/v) lecithin and incubating for $24 \mathrm{~h}$ at $25^{\circ} \mathrm{C}$. The radius of clearing in the gel was measured and a standard curve was constructed to relate radius of clearing to concentrations of the purified GCAT/LPS

Lecithin (from egg, Sigma) $0.1 \mathrm{mg}$ emulsified in $9 \mu \mathrm{l}$ $0.1 \mathrm{M}$ Tris- $\mathrm{HCl}, \mathrm{pH} 7.5)$ was incubated with sample at $37^{\circ} \mathrm{C}$ for 10,30 , and $60 \mathrm{~min}$, respectively. The enzymic activity was destroyed by addition of $9 \mu 10 \%$ trichloracetic acid (TCA) directly after incubation. Phospholipase activity was measured by detecting the release of free fatty acids from lecithin using a kit (Wako Chemicals GmbH, Germany) in a colorimetric method for the quantitative determination of nonesterified fatty acids following the manufacturer's instructions.

Rabbit antisera. Rabbit antiserum to rainbow trout high density lipoprotein ( $\alpha$ RTHDL) was a gift from $D r$ E. R. Skinner, Department of Biochemistry, University of Aberdeen (Skinner \& Rogie 1978). Rabbit antiserum to the ECP was prepared as previously described (Ellis et al. 1988).

Rabbit antiserum to Atlantic salmon whole serum ( $\mathrm{R} \alpha$ SS) was raised by subcutaneous injection of $0.5 \mathrm{ml}$ Atlantic salmon serum emulsified in complete Freunds adjuvant. A booster injection of $0.5 \mathrm{ml}$ serum without adjuvant was given 6 wk later and the rabbit antiserum obtained 10 d later.

Crossed immunoelectrophoresis (CIE). CIE was performed using the Multiphor System (LKB) as described by Wallenborg \& Anderssonn (1978). Briefly, 20 ul of each sample was electrophoresed in the first dimension at $10 \mathrm{~V} \mathrm{~cm}^{-1}$ for $70 \mathrm{~min}$. The second dimension gel contained $3 \%(\mathrm{v} / \mathrm{v})$ rabbit antiserum and electrophoresis was conducted at $2 \mathrm{~V} \mathrm{~cm}^{-1}$ for $16 \mathrm{~h}$ in $0.05 \mathrm{M}$ tris-barbiturate buffer, $\mathrm{pH}$ 8.6. Gels were pressed, dried and stained with Coomassie brillant blue. In studies of the effect of the GCAT/LPS on the electrophoretic mobility of various serum components, the latter were incubated with the toxin for $30 \mathrm{~min}$ at $25^{\circ} \mathrm{C}$ prior to the CIE.

\section{RESULTS}

\section{Purification and identification of three salmon serum proteins}

The void volume fractions 16 and 17 from FPLC-gel filtration were collected (Fig. 1A). In native PAGE: 
Fig. 1. (A) Profile of FPLC-gel filtration of salmon serum. (B) Profile of FPLC-anion exchange chromatography of fractions 22 and 23 from gel filtration. (C) Profile of FPLC-anion exchange chromatography of fractions 24 and 25 from gel filtration

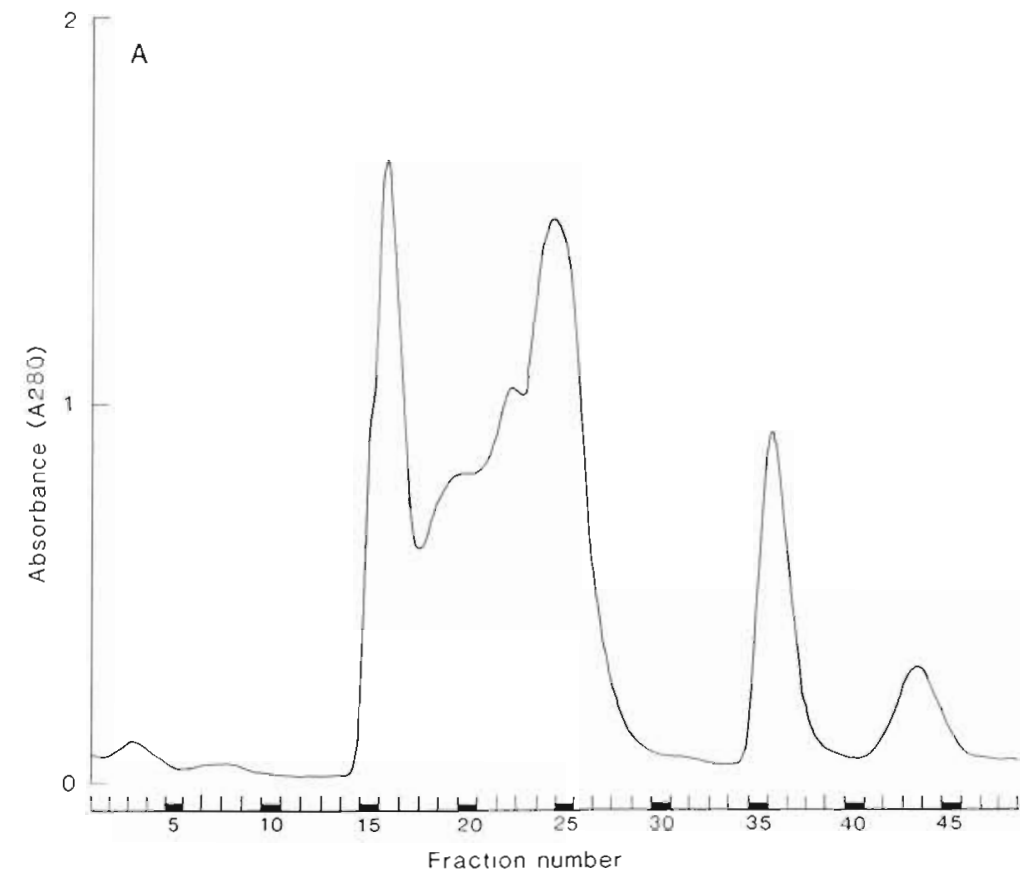

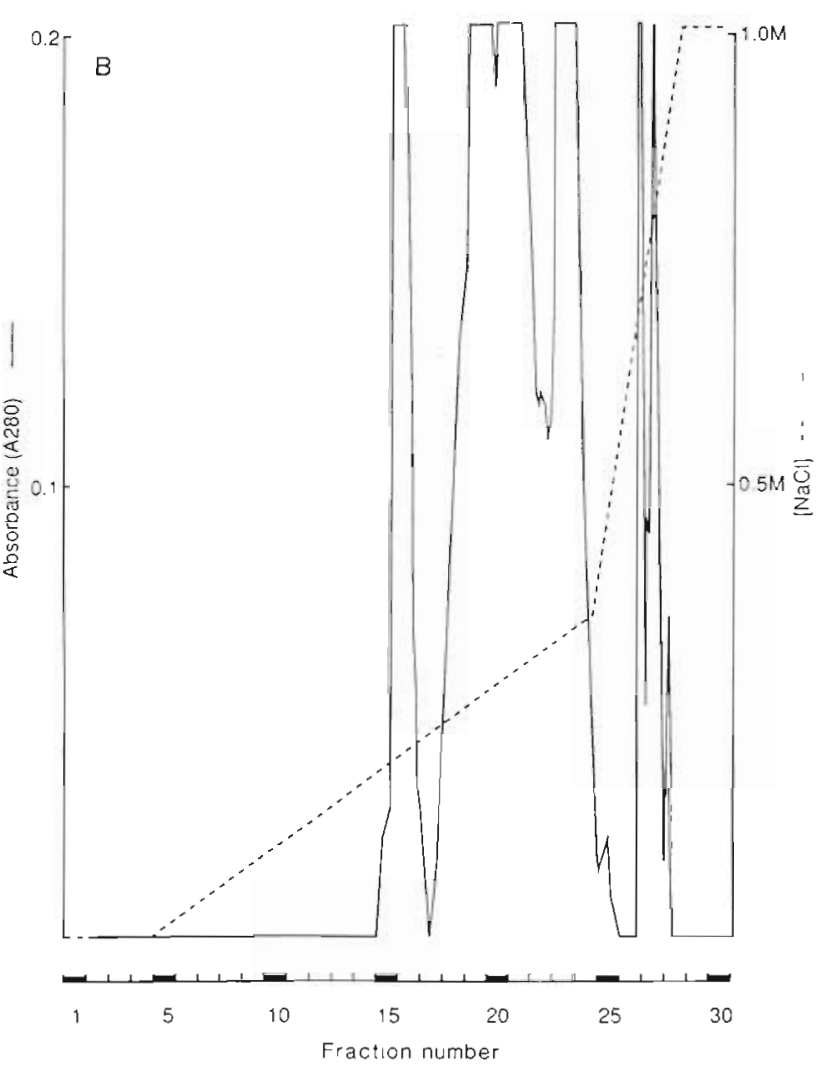

these fractions contained a high molecular weight protein (Fig. 2A), which in SDS-PAGE (Fig. 2B) disaggregated into several components with a pattern similar to that of low density lipoprotein (LDL) as described by others (Chapman et al. 1978). These fractions were comprised of $0.49 \mathrm{mg} \mathrm{ml}^{-1}$ protein, $1.55 \mathrm{mg} \mathrm{ml}^{-1}$ total

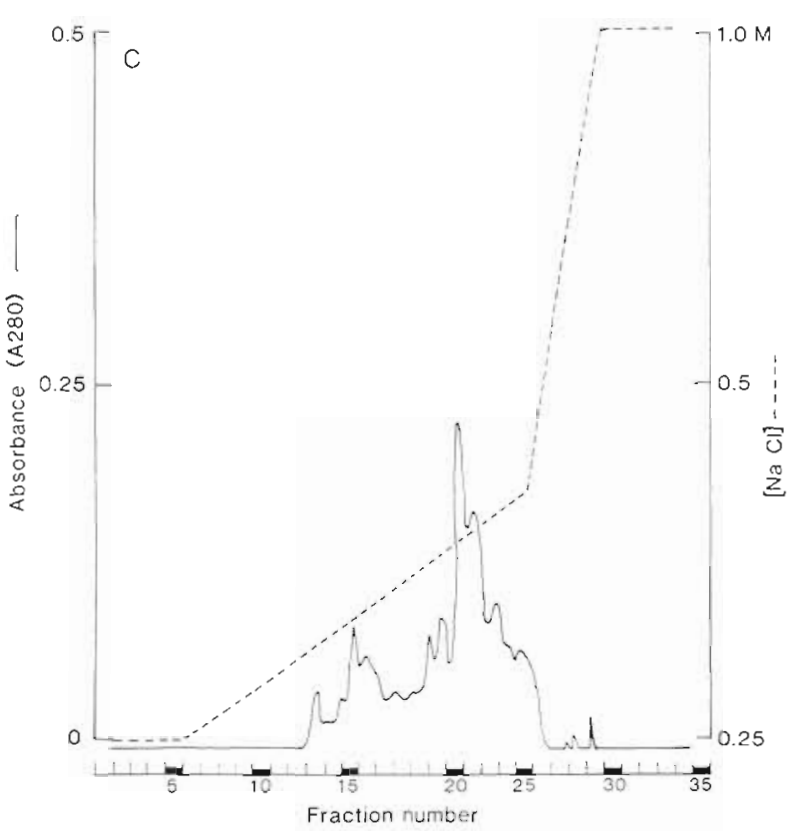

lipids, and $0.42 \mathrm{mg} \mathrm{ml}^{-1}$ total cholesterols which was also comparable to the data for rainbow trout LDL reported by Fremont et al. (1981) and Babin \& Vernier (1989). These fractions did not cross react with $R \alpha$ RTHDL. These data indicate that these fractions contained a LDL-like protein.

Fractions 22 and 23 collected from FPLC-gel filtration (Fig. 1A) were applied to an FPLC-anion exchange column. Fractions 18 from this separation (Fig. 1B), in SDS-PAGE (Fig. 2C), contained 2 protein bands, 28 and $14 \mathrm{kDa}$. In CIE this fractions produced 2 precipitin arcs with R $\alpha$ SS (see Fig. 7B), the major one of which 
was also produced by $\mathrm{R} \alpha$ RTHDL (Fig. 3). Therefore, we defined it to be high density lipoprotein (HDL) (Skinner \& Rogie 1978, Babin 1987, Ooshiro et al. 1988). The HDL fraction contained $0.27 \mathrm{mg} \mathrm{ml}^{-1}$ protein, $0.42 \mathrm{mg} \mathrm{ml}^{-1}$ total lipids, and $0.18 \mathrm{mg} \mathrm{ml}^{-1}$ total cholesterols.

Fractions 24 and 25 collected from FPLC-gel filtration (Fig. 1A) were also applied to a FPLC-anion exchange column. Fraction 20 (Fig. 1C) in SDS-PAGE produced a single $68 \mathrm{kD}$ a protein band (Fig. 2D) which was fast migrating in native PAGE (Fig. 4). This protein could be visualised as a transparent spot against a
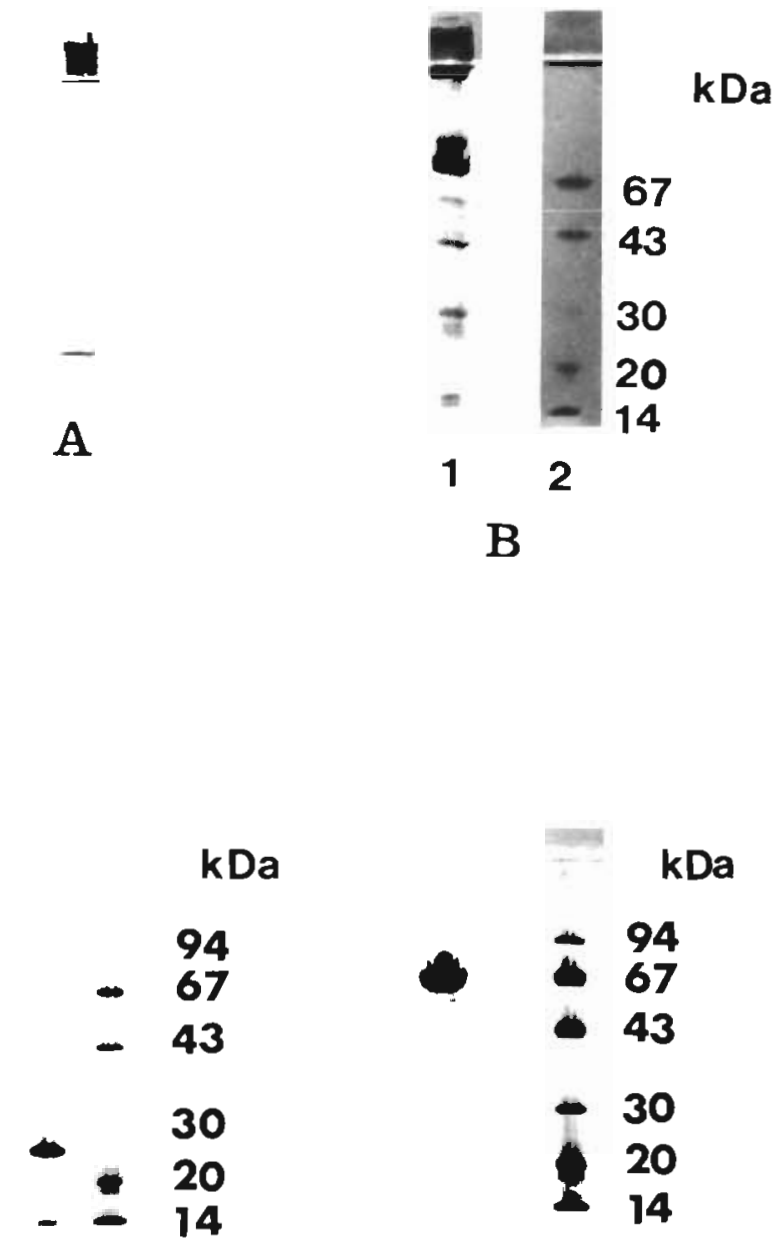

12

\section{C}

Fig. 2. (A) Native PAGE (phastgel) of salmon LDL-like fraction (fractions 16 and 17 of gel filtration fractionation of salmon serum) stained with silver (1.0 $\mu \mathrm{g}$ protein). (B) 1: SDS-PAGE of LDL-like fraction stained with silver (phastgel) $(2.0 \mu \mathrm{g}) ; 2$ : marker proteins. (C) 1. SDS-PAGE of HDL fraction stained with silver (phastgel) $(0.3 \mu \mathrm{g})$ : 2 : marker proteins. (D) 1: SDSPAGE of albumin fraction stained with silver (phastgel) $(1.0 \mu \mathrm{g}) ; 2$ : marker proteins brown background following immersion of the gel in a saturated iodine solution for $30 \mathrm{~min}$ to $1 \mathrm{~h}$. Native bovine and rabbit serum albumins gave identical results. Consequently, this protein was identified as salmon serum albumin. This albumin fraction contained $0.40 \mathrm{mg} \mathrm{ml}^{-1}$ protein, $0.33 \mathrm{mg} \mathrm{ml}^{-1}$ total lipids, and $0.02 \mathrm{mg} \mathrm{ml}^{-1}$ total cholesterols. Also, this salmon serum albumin fraction did not cross react with $R \alpha$ RTHDL.

Enhancement of lecithinase activity of GCAT/LPS by addition of salmon serum, LDL-like fraction, HDL or albumin

A standard curve, produced by plotting the radius of clearing in the lecithin-agar plate against log of GCAT/ LPS concentration, showed a linear relationship over the enzyme concentrations used (Fig. 5). By comparing the radii of clearing produced by the mixtures of GCAT/LPS and the various serum components with the values in the standard curve, it can be seen that the serum components enhanced the lecithinase activity of the GCAT/LPS equivalent to at least a 4 -fold increase in the enzyme concentration (Table 1). The serum or serum components alone, used as controls, had no lecithinase activity.

\section{Kinetics of enhancement of phospholipase activity of GCAT/LPS by addition of LDL-like fraction, HDL or albumin}

In order to gain information on the rate of enhancement of phospholipase activity, the effect of the lipoproteins and albumin on the release of free fatty acids from lecithin by the GCAT/LPS was monitored over time. Fig. 6 indicates that the serum components had little effect on the reaction rate over the first 30 min but

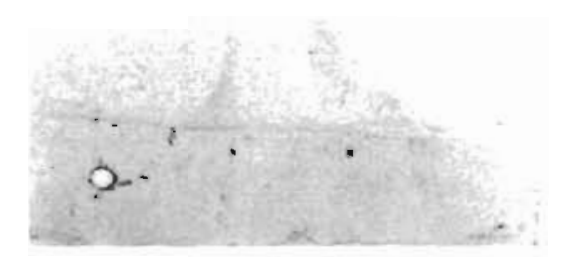

Fig. 3. CIE of HDL fraction. First dimension is purified HDL. Second dimension is rabbit anti rainbow trout HDL anti-serum 
during the next 30 min an appreciable enhancement of reaction rate was observed for all serum components. Relevant controls and concentration of reactants are shown in Table 2. The controls demonstrate that no detectable phospholipase activity was associated with the serum components and although HDL, LDL-like fraction and albumin contained lipids, no release of free fatty acids from them by the GCAT/LPS toxin was detected in the absence of lecithin substrate.
A
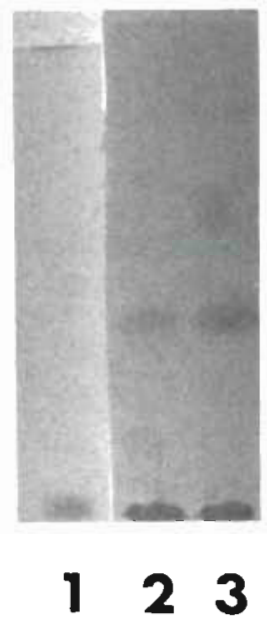
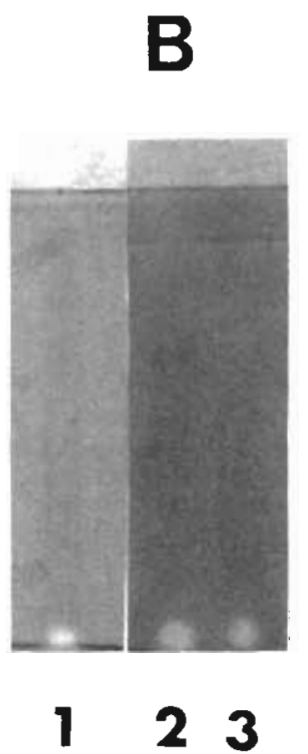

Fig. 4. Native phastgel stained with (A) Coomassie brilliant blue or (B) saturated iodine solution. 1: Purified salmon serum albumin $(0.4 \mu \mathrm{g}) ; 2$; bovine serum albumin $(1.0 \mu \mathrm{g})$; 3 : rabbit serum albumin $(1.0 \mu \mathrm{g})$

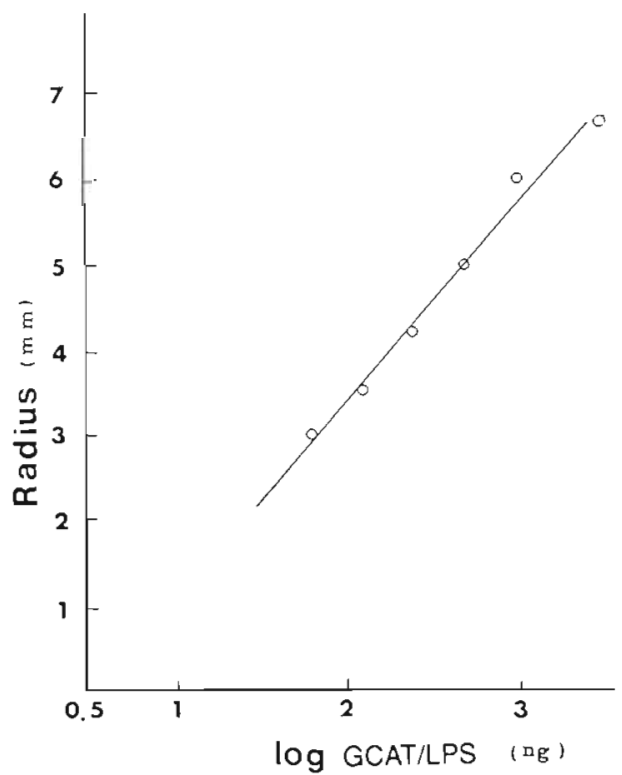

Fig. 5. Calibration curve of GCAT/LPS protein concentration against radius of transparent zone (from Table 1) in lecithin gel

Effects of adding rainbow trout serum, LDL-like fraction, HDL or albumin on haemolytic activity of GCAT/LPS

The addition of all the serum protein fractions inhibited the haemolytic activity of GCAT/LPS between 2 and 128 -fold in the $2 \mathrm{~h}$ assay. However, after $7 \mathrm{~h}$, albumin had enhanced the activity 4 -fold. After $24 \mathrm{~h}$, the

Table 1. Lecithinase activity measured as zone of clearing in lecithin agar plates due to Aeromonas salmonicida GCAT/LPS, salmon serum components, and mixtures of the two after $24 \mathrm{~h}$ (at $25^{\circ} \mathrm{C}$ ) incubation

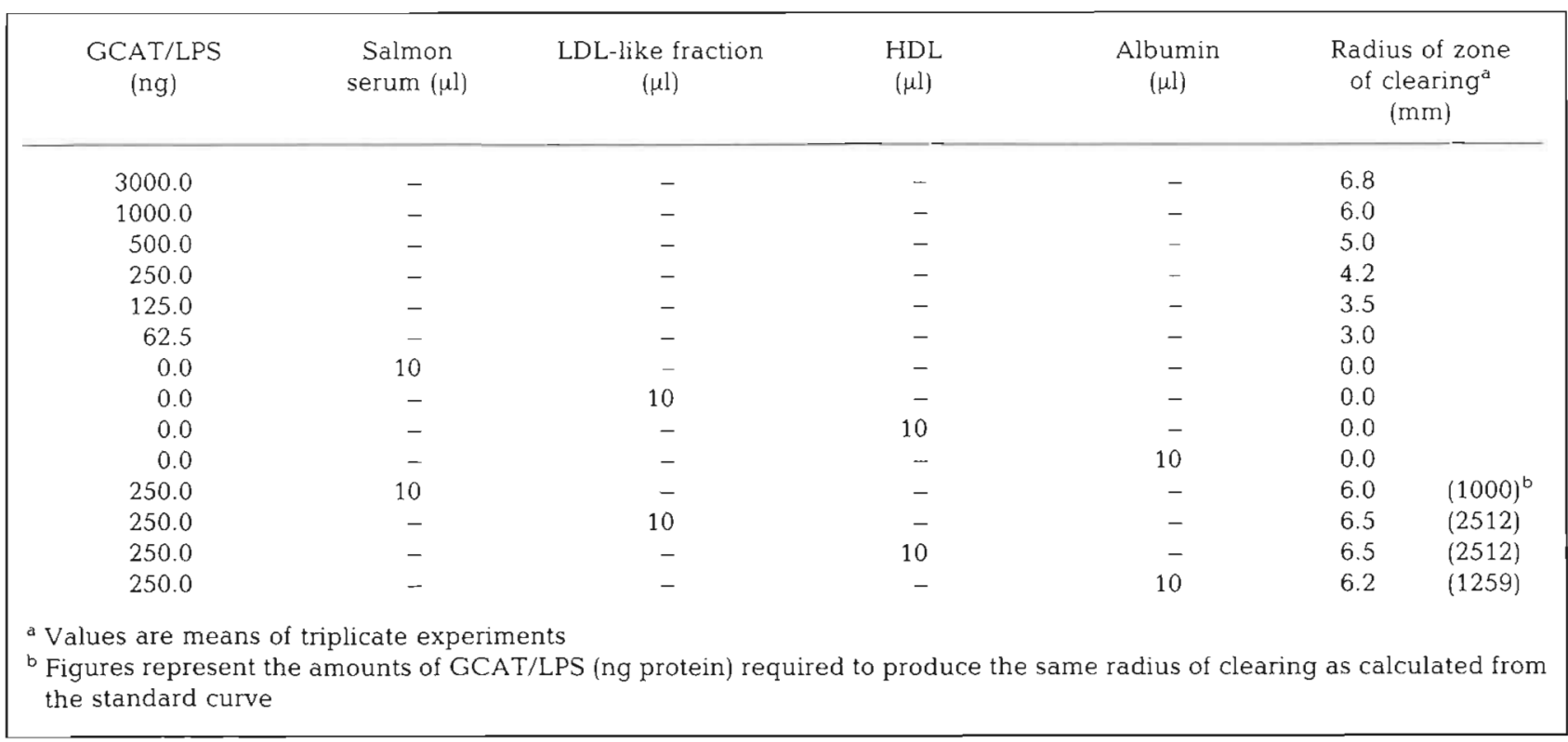


Table 2. Release of free fatty acids from lecithin by different mixtures of the Aeromonas salmonicida GCAT/LPS and salmon serum components after incubation at $37^{\circ} \mathrm{C}$ for 10,30 , and $60 \mathrm{~min}$. Total volume of reaction mixtures was $11 \mu \mathrm{l}$. +: sample(s) added; - : sample(s) omitted

\begin{tabular}{|c|c|c|c|c|c|c|c|c|c|}
\hline \multirow{2}{*}{$\begin{array}{c}\text { GCAT/LPS } \\
(2.5 \mathrm{ng})\end{array}$} & \multirow{2}{*}{$\begin{array}{l}\text { Lecithin } \\
(0.1 \mathrm{mg})\end{array}$} & \multirow{2}{*}{$\begin{array}{l}\text { LDL-like } \\
(0.49 \mu \mathrm{g})\end{array}$} & \multirow{2}{*}{$\begin{array}{c}\text { HDL } \\
(0.47 \mu \mathrm{g})\end{array}$} & \multirow{2}{*}{$\begin{array}{l}\text { Albumin } \\
(0.40 \mu \mathrm{g})\end{array}$} & \multirow{2}{*}{$\begin{array}{c}0.1 \mathrm{M} \\
\text { tris- } \mathrm{HCl} \\
\mathrm{pH} 7.5\end{array}$} & \multicolumn{4}{|c|}{$\mathrm{mM}$ free fatty acids detected ${ }^{\mathrm{a}}$} \\
\hline & & & & & & $0 \mathrm{~min}$ & $10 \mathrm{~min}$ & $30 \mathrm{~min}$ & $60 \mathrm{~min}$ \\
\hline+ & + & + & - & - & -- & 0 & 0.175 & 0.295 & 0.870 \\
\hline+ & + & - & + & - & - & 0 & 0.135 & 0.350 & 0.950 \\
\hline+ & + & - & - & + & - & 0 & 0.130 & 0.250 & 0.750 \\
\hline+ & + & - & - & - & + & 0 & 0.125 & 0.260 & 0.575 \\
\hline+ & - & - & - & - & + & 0 & 0.000 & 0.000 & 0.000 \\
\hline+ & - & + & - & - & + & 0 & 0.000 & 0.000 & 0.000 \\
\hline+ & - & - & + & - & + & 0 & 0.000 & 0.000 & 0.000 \\
\hline+ & - & - & - & + & + & 0 & 0.000 & 0.000 & 0.000 \\
\hline- & + & - & - & - & + & 0 & 0.000 & 0.000 & 0.000 \\
\hline- & + & + & - & - & + & 0 & 0.000 & 0.000 & 0.000 \\
\hline- & + & - & + & - & + & 0 & 0.000 & 0.000 & 0.000 \\
\hline- & + & - & - & + & + & 0 & 0.000 & 0.000 & 0.000 \\
\hline
\end{tabular}

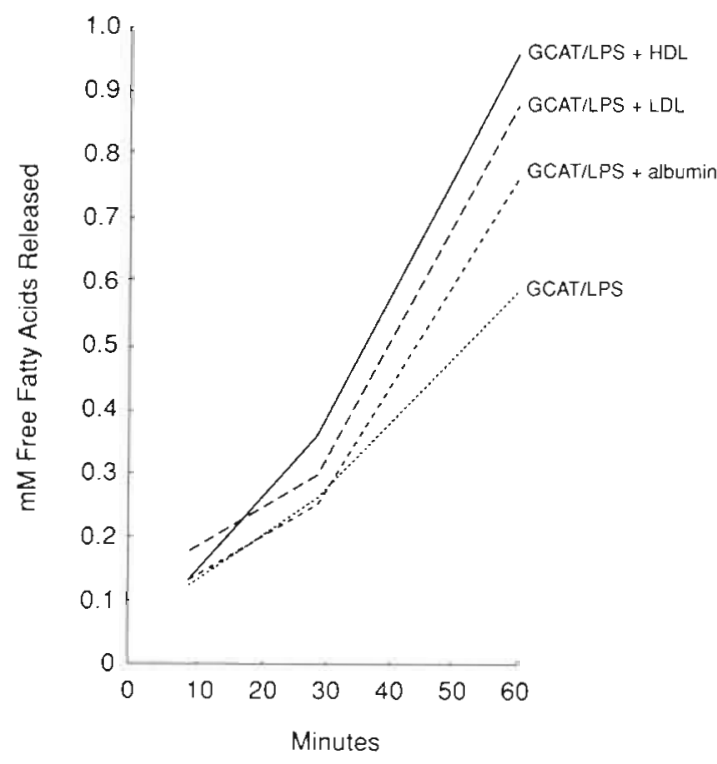

Fig. 6. Release of free fatty acids from lecithin by GCAT/LPS in the presence or absence of salmon serum components monitored over time

enhancement of the activity by albumin was 32 -fold and trout serum enhanced the activity by 4 -fold, but HDL and LDL-like components inhibited the activity by 2 and 16 -fold, respectively (Table 3 ).

Effects on electrophoretic mobility of salmon serum, LDL-like fraction, HDL or albumin after incubation with $A$. salmonicida ECP or GCAT/LPS

As shown in Figs. $7 \& 8$, several components in salmon serum migrated faster in the CIE after incuba- tion with Aeromonas salmonicida ECP (compare Figs. $7 \mathrm{~A} \& \mathrm{~B}$ ) or the GCAT/LPS (compare Figs. $7 \mathrm{~A} \& \mathrm{C}$ ). An increase in the electrophoretic mobility of HDL in serum was observed after incubation with GCAT/LPS (compare Figs. 8A \& B). The major component in the LDL-like fraction, HDL, and albumin migrated faster in the CIE after incubation with GCAT/LPS (compare, respectively, Figs. 9A \& B, Figs. 9B \& E, and Figs. 9C \& F). The migration of the GCAT/LPS remained unchanged after incubation with salmon serum (data not shown), the precipitation arc formed against $\mathrm{R} \alpha$ $\mathrm{ECP}$ being in precisely the same region as in CIE of GCAT/LPS without serum (Lee \& Ellis 1990).

Table 3. Effect of salmonid serum components on the haemolytic activity of Aeromonas salmonicida GCAT/LPS. Protein concentration of GCATG/LPS was $25 \mu \mathrm{g} \mathrm{ml}^{-1}$, LDLlike fraction $0.49 \mathrm{mg} \mathrm{ml}^{-1}$. HDL $0.47 \mathrm{mg} \mathrm{ml}^{-1}$, and albumin 0.4 $\mathrm{mg} \mathrm{ml} \mathrm{m}^{-1}$. The ratio of sample to toxin was $1: 1 \mathrm{v} / \mathrm{v}$

\begin{tabular}{lrrr}
$\begin{array}{l}\text { Erythrocytes incubated } \\
\text { with: }\end{array}$ & \multicolumn{3}{c}{ Haemolytic titres $\left(\log _{2}\right)$} \\
& $2 \mathrm{~h}$ & $7 \mathrm{~h}$ & $24 \mathrm{~h}$ \\
\hline GCAT/LPS + PBS & 12 & 18 & 21 \\
GCAT/LPS + trout serum & 5 & 17 & 23 \\
GCAT/LPS + LDL-like fraction & 11 & 15 & 17 \\
GCAT/LPS + HDL & 11 & 17 & 20 \\
GCAT/LPS + Albumin & 11 & 20 & 26 \\
Trout serum + PBS & 0 & 0 & 0 \\
LDL-like fraction + PBS & 0 & 0 & 0 \\
HDL + PBS & 0 & 0 & 0 \\
Albumin + PBS & 0 & 0 & 0 \\
a Rainbow trout serum used in this study was obtained \\
from the same fish that supplied the erythrocytes
\end{tabular}




\section{DISCUSSION}

Recently a potent lethal cytolysin (GCAT/LPS) was identified in the extracellular products of Aeromonas salmonicida (Lee \& Ellis 1990). Previous workers have studied the enzymic characteristics of GCAT and shown that this molecule is activated by mammalian serum albumin and apolipoprotein A-1 (Buckley et al. 1982). The aim of the present study was to investigate possible similar effects of salmonid serum proteins on the activity of the GCAT/LPS toxin which may aid in furthering the understanding of the pathogenic mechanisms of A. salmonicida.

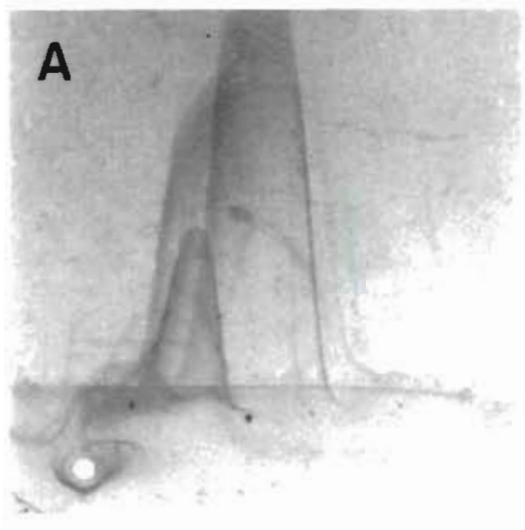

B

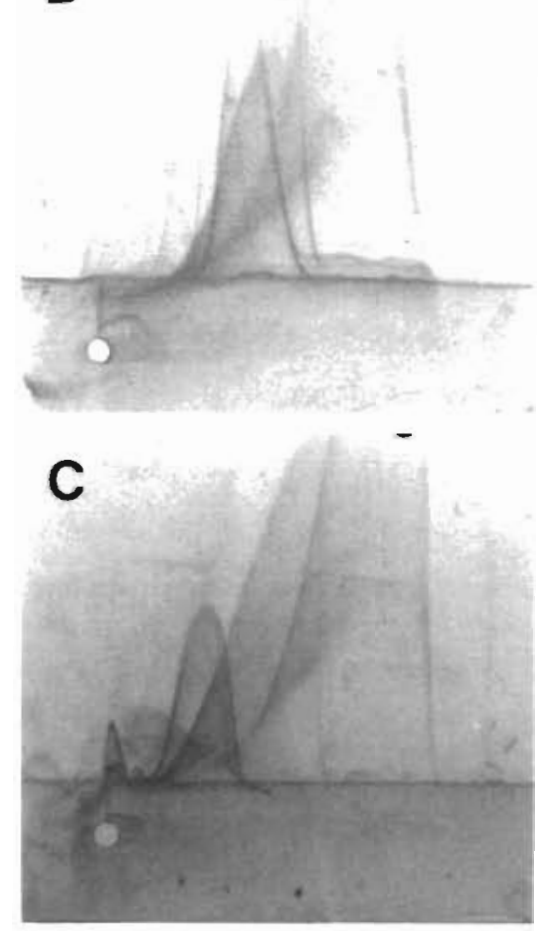

Fig. 7. Effect on the electrophoretic mobility of salmon serum proteins after incubation of whole salmon serum with (B) ECP or (C) GCAt/LPS for 30 min. (A) Salmon serum only
Initial experiments showed that whole salmon serum did in fact enhance the phospholipase activity of the purified toxin and so further experiments were performed to identify which components in the serum were responsible. The evidence presented here indicates that LDL-like protein, HDL, and serum albumin have appreciable effects on the phospholipase and haemolytic activities of the GCAT/LPS toxin and that the latter changes the electrophoretic characteristics of these serum components. The evidence for identifying the serum components as the LDL-like fraction, HDL, and albumin is discussed below.

The partially purified LDL-like protein of salmon serum was composed of a single high molecular weight component in native PAGE and in agreement with others (Fremont et al. 1981, Babin \& Vernier 1989) also contained a high percentage of lipids and cholesterols. In the CIE study, this component produced 2 precipitation arcs against the R $\alpha$ SS. In SDS-PAGE, a complex pattern of proteins was obtained which was almost identical to that reported by others for LDL (Chapman et al. 1978, Babin 1987). Therefore, we defined this component as LDL-like although it may contain some very low or intermediate density lipoprotein.
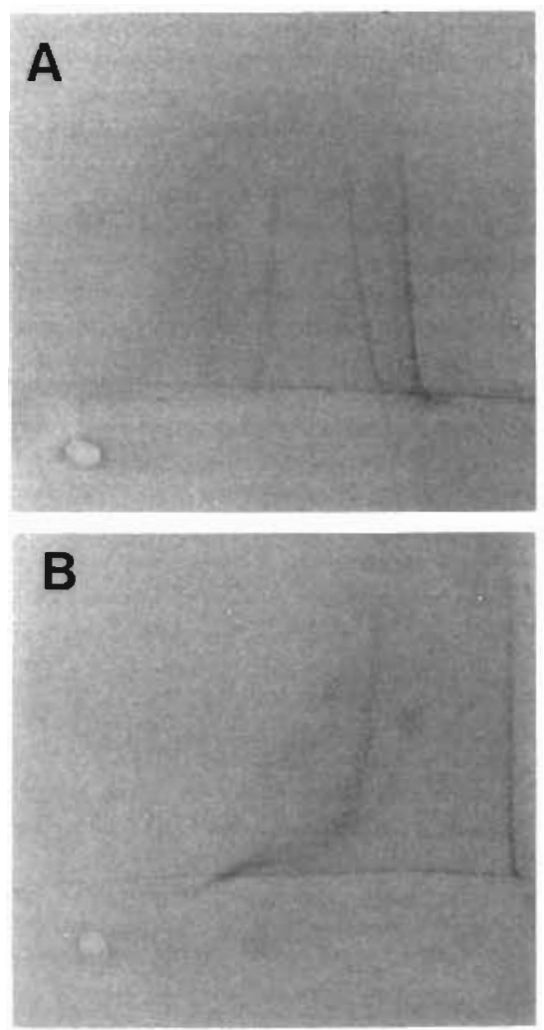

Fig. 8. Effect on the electrophoretic mobility of salmon serum HDL after incubation of serum with GCAT/LPS. (A) Salmon serum only; (B) salmon serum plus GCAT/LPS. Second dimension: R $\propto$ RTHDL 
The HDL protein purified from salmon serum was composed of 2 protein bands (28 and $14 \mathrm{kDa}$ ) in SDSPAGE, which is comparable to previous studies on fish (Skinner \& Rogie 1978, Babin 1987, Ooshiro et al. 1988, Smith et al. 1988). In addition, this fraction precipitated with R $\alpha$ RTHDL and also contained lipids and cholesterols providing convincing evidence that this component was HDL.

The component identified as salmon serum albumin was fast-migrating in electrophoresis, indicating a high negative charge in the native state. In SDS-PAGE, the protein had a molecular mass of $68 \mathrm{kDa}$. These data are consistent with albumins identified from other fish and vertebrates (Perrier et al. 1977, Fellows \& Hird 1981, Davidson et al. 1988, 1989). Furthermore, this protein was characterised as salmon serum albumin by using an iodine staining method (Lee \& Ellis 1991a) which is specific for identifying albumin in native PAGE.

In the phuspholipase assays performed in the present study, HDL, the LDL-like fractions, and albumin all enhanced the activity of the GCAT enzyme, though enhancement appeared to be greater for HDL and the LDL-like fraction than for albumin. The kinetic assays showed that the increased rate of reaction was not immediate but appeared after 30 mins incubation of the reaction mixture.

The effect of serum and the prirified serum components on the haemolytic activity of the GCAT/LPS was more complex. After $2 \mathrm{~h}$ of incubation with erythrocytes the individual serum components slightly inhibited haemolytic activity while whole serum produced a marked inhibition. However, by $24 \mathrm{~h}$, serum and the purified albumin had enhanced the haemolytic activity of the GCAT/LPS, while appreciable inhibition by the LDL-like fraction and HDL was still observed.

The initial inhibition of the haemolytic activity of the GCAT/LPS by serum and the serum components studied may be due to substrate competition from the phospholipids present on the lipoproteins and albumin which may be more accessible substrates than those in the erythrocyte membrane. Nevertheless, the net enhancement of haemolytic activity by serum after $24 \mathrm{~h}$ incubation is significant and could be due to the marked enhancement of haemolytic activity by the albumin.

Inhibition of haemolytic activity of Aeromonas salmonicida ECP by salmonid serum in assays monitored
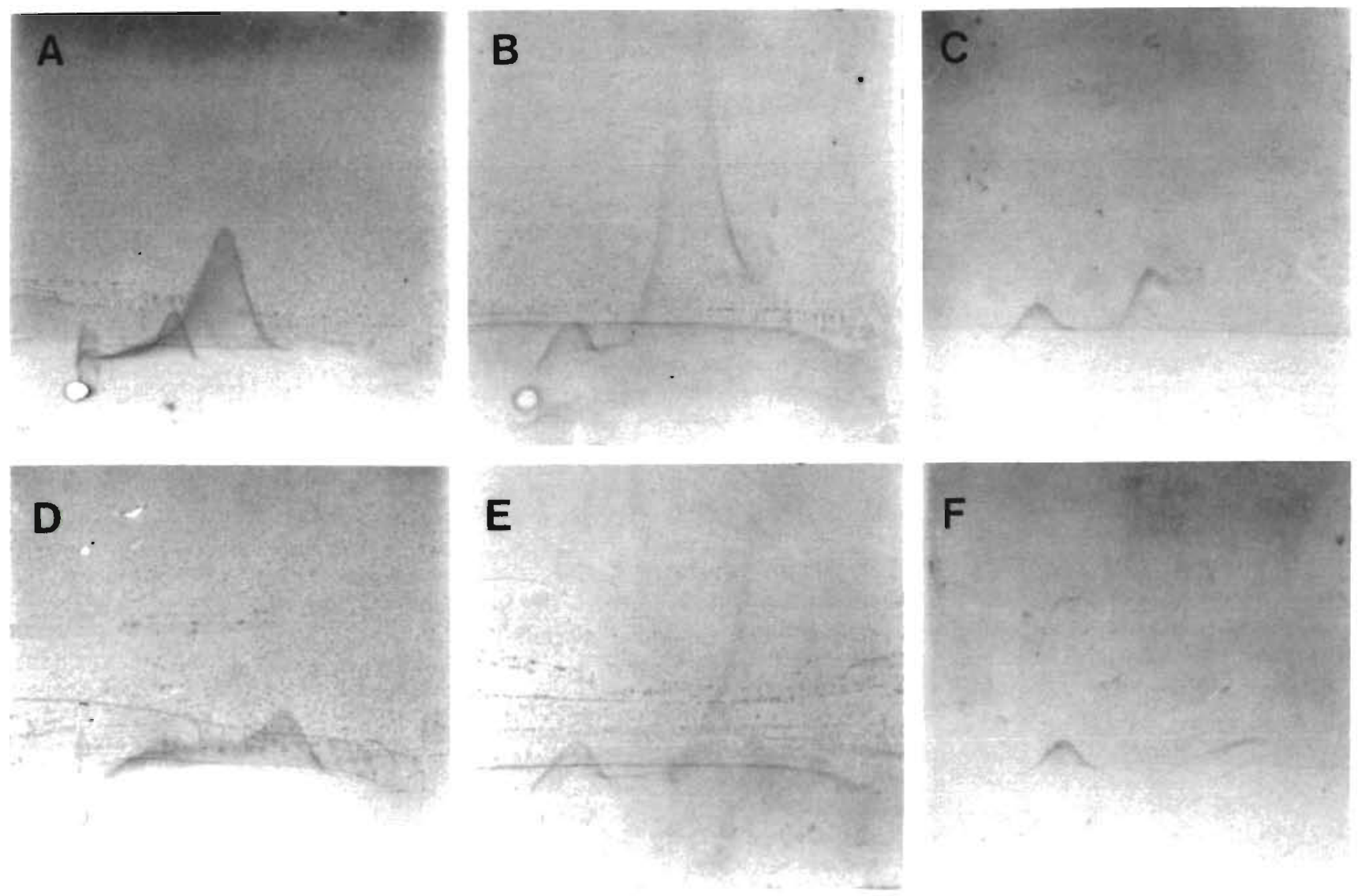

Fig. 9. Effect on the electrophoretic mobility of purified salmon serum proteins after incubation with GCAT/LPS. (A), (B), (C) CIE of purified serum proteins only; (D). (E) (F) CIE of purified serum proteins after incubation with GCAT/LPS for $30 \mathrm{~min}$ at $25^{\circ} \mathrm{C}$. First dimension: (A), (D) salmon LDL-like protein; (B), (E) salmon HDL; (C). (F) salmon albumin. Second diemension: rabbit antiwhole salmon serum 
for less than $2 \mathrm{~h}$ have been reported previously (Munro et al. 1980, Rockey et al. 1989). Attempts to identify the serum inhibitor showed it was insensitive to selected proteases, was not removed by centrifugation at 100000 $\times g$ for 60 min but was sensitive to incubation at $60^{\circ} \mathrm{C}$ for 30 min (Rockey et al. 1989). These workers also postulated that the serum inhibition may be due to a competitive inhibitor of the haemolysin, having structural similarity to the haemolysin substrate binding site on the erythrocyte membrane. The characteristics of the haemolysin inhibition factor in the serum described by Rockey et al. (1989) is consistent with it being a lipoprotein with a high phospholipid content and is in agreement with the findings reported in the present paper.

The significant inhibition of haemolytic activity by LDL-like protein after $24 \mathrm{~h}$ may indicate some degree of binding between this protein and GCAT/LPS such that haemolytic activity is sterically hindered. However, if this is the case the binding is not strong (see below).

In the present study we also found that the GCAT/LPS increased the relative electrophoretic mobility of several salmon serum proteins after in vitro incubation. A similar phenomenon was observed with the LDL-like fraction, HDL, and albumin. Although the reason for this increase in electrophoretic mobility of the serum proteins is still unclear, it is evident that the GCAT/LPS significantly affects certain physical properties of the serum albumin and the major lipoproteins. From work in mammals it is known that LPS can bind to HDL resulting in an increased electrophoretic mobility of the complex (Freudenberg et al. 1980). However, in the present study there was no evidence that the GCAT/LPS bound firmly to any of the serum proteins as the mobility of the GCAT/LPS in CIE (developed with $\mathrm{R} \alpha \mathrm{ECP}$ ) remained unaffected by prior incubation with salmon serum.

From our previous investigations (Lee \& Ellis 1989. 1990) the GCAT/LPS is a haemolysin, leucocytolysin, cytotoxin, and the major lethal factor produced by Aeromonas salmonicida. The mechanism of the lethal effect is still unknown and histopathological studies (Lee \& Ellis 1991b) have revealed minimal cytonecrotic effects. The enhancement of lecithinase activity of the cytolysin by salmon serum, the LDL-like fraction, HDL, and albumin suggests that the lethality of the GCAT/LPS may be enhanced by these effects when the cytolysin is i.p. injected into salmon. Furthermore, as lipoproteins and albumin are concerned in the transportation/metabolism of lipids and cholesterols in vertebrates (Terpstra et al. 1982, Dolphin 1985, Peters 1985, Babin \& Vernier 1989), the present results provide an insight into the possible perturbation of the fish's metabolism which could play a significant role in the pathogenesis of furunculosis and the mechanisms of lethal toxicity exercised by this potent bacterial toxin.
Acknowledgements. K.-K. L. is grateful for a Ph.D. studentship from the Ministry of Education, Republic of China.

\section{LITERATURE CITED}

Babin, P. J. (1987). Plasma lipoprotein und apolipoprotein distribution as a function of density in the rainbow trout (Salmo gairdneri). Biochem. J. 246: 425-429

Babin, P. J., Vernier, J.-M. (1989). Plasma lipoproteins in fish. J. Lipid Res. 30: 467-489

Bradford, M. M. (1976). A rapid and sensitive method for the quantitation of microgram quantities of protein using the principle of protein-dye binding. Analyt. Biochem. 72 $248-254$

Buckley, J. T. (1982). Substrate specificity of bacterial glycerophospholipid:cholesterol acyltransferase. Biochemistry 21: 6699-6703

Buckley, J. T (1983). Mechanism of action of bacterial glycerophospholipid:cholesterol acyltransferase. Biochemistry 22: $5490-5493$

Buckley, J. T., Halasa, L. N., MacIntyre, S. (1982). Purification and partial characterisation of a bacterial phospholipidcholesterol acyltransferase. J. biol. Chem. 255: 3320-3325

Buckley, J. T., McLeod, R., Frohlich, J. (1984). Action of a microbial glycerophospholipid:cholesterol acyltransferase on plasma from normal and LCAT-deficient subjects. J. Lipid Res. 25: 913-918

Chapman, M. J., Goldstein, S., Mills, G. L., Leger, C. (1978). Distribution and characterisation of serum lipoproteins and their apoproteins in the rainbow trout (Salmo gairdnerii). Biochemistry 17: 4455-4464

Davidson, W S., Birt, V. L., Birt, T P., Green, J. M. (1988). Palmitate-binding, serum albumin-like proteins in salmonids. FEBS Lett. 233: 299-302

Davidson, W. S., Bartlett, S. E., Birt, I. P., Birt, V L., Green, J. M. (1989). Identification and purification of serum albumin from rainbow trout (Salmo gairdneri). Comp. Biochem. Physiol. 93B: 5-9

Dolphin, P. J. (1985). Lipoprotein metabolism and the role of apolipoproteins as metabolic programmers. Can. J. Biochem. Cell Biol. 63: 850-869

Ellis, A. E., Stapleton, K. J., Hastings, T S. (1988). The humoral immune response of rainbow trout (Salmo gairdneri) immunised by various regimes and preparations of Aeromonas salmonicida antigens. Vet. Immunol. Immunopath. 19: 153-164

Fellows, F. C. I., Hird, F. J. R. (1981). Fatty acid binding proteins in the serum of various animals. Comp. Biochem. Physiol. 68B: 83-8?

Fremont, L., Leger, C., Boudon, M. (1981). Fatty acid composition of lipids in the trout - II. Fractionation and analysis of plasma lipoproteins. Comp. Biochem. Physiol. 69B: $107-113$

Freudenberg, M. A., Bog-Hansen, T. C., Back, U., Galanos, C. (1980). Interaction of lipopolysaccharides with plasma highdensity lipoprotein in rats. Infect. Immun. 28: 373-380

Hastings, T. S., Ellis, A. E. (1985). Differences in the production of haemolytic and proteolytic activities by various isolates of Aeromonas salmonicida. In: Ellis, A. E. (ed.) Fish and shellfisch pathology. Academic Press, London, p. $69-77$

Lee, K.-K., Ellis, A. E.(1989). The quantitative relationship of lethality between extracellular protease and extracellular haemolysin of Aeromonas salmonicida in Atlantic salmon (Salmo salar L.). FEMS Microbiol. Lett. 61: 127-132 
Lee, K.-K., Ellis, A. E. (1990). Glycerophospholipid:cholesterol acyltransferase complexed with lipopolysaccharide (LPS) is a major lethal exotoxin and cytolysin of Aeromonas salmonicida: LPS stabilizes and enhances toxicity of the enzyme. J. Bacteriol. 172: 5382-5393

Lee, K.-K., Ellis, A. E. (1991a). A novel method for specific visualisation of serum albumin in polyacrylamide gels by iodine staining. Electrophoresis 12: 382-383

Lee, K.K., Ellis, A. E. (1991b). The role of the lethal extracellular cytolysin of Aeromons salmonicida in the pathology of furunculosis. J. Fish. Dis. (in press)

Munro, A. L. S., Hastings, T S., Ellis, A. E., Liversidge, J. (1980). Studies on an ichthyotoxic material produced extracellularly by the furunculosis bacterium, Aeromonas salmonicida. In: Ahne, W. (ed.) Fish diseases. SpringerVerlag, Berlin, p. 98-106

Ooshiro, Z., Yu, F.-G., Hayashi, S., Hino, K., Kojima, H. (1988). Apolipoprotein of high density lipoprotein of eel serum. Mem. Fac. Fish. Kagoshima Univ. 37: 25-3.3

Perrier, H., Perrier, C., Peres, G., Gras, J. (1977). The perchlorosoluble proteins of the serum of the rainbow trout (Salmo gairdnerii Richardson): albumin like and haemoglobin binding fraction. Comp. Biochem. Physiol. 57B: 325-327

Responsible Subject Editor: T. Evelyn, Nanaimo, B. C., Canada
Peters, T Jr (1985). Serum albumin. Adv. Protein Chem. 37 $161-245$

Rockey, D. D., Shook, L. A., Fryer, J. L., Rohovec, J. S. (1989). Salmonid serum inhibits haemolytic activity of the secreted haemolysin of Aeromonas salmonicida. J. Aquat. Anim. Health 1: 263-268

Skinner, E. R. Rogie, A. (1978). The isolation and partial characterisation of the serum lipoproteins and apolipoproteins of the rainbow trout. Biochem. J. 173: 507-520

Smith, M. A. K. McKay, M. C., Lee, R. F. (1988). Catfish plasma lipoproteins: in vivo studies of apoprotein systhesis and catabolism. J. exp. Zool. 246: 223-235

Subbaiah, P. V., Albers, J. J., Chen, C. H., Bagdade, J. D (1980). Low density lipoprotein-activated lysolecithin acylation by human plasm lecithin-cholesterol acyltransferase. J. biol. Chem. 255: 9275-9280

Terpstra, A. H. M., Sanchez-Muniz, F. J., West, C. E., Woodward, C. J. H. (1982). The density profile and cholesterol concentration of serum lipoproteins in domestic and laboratory animals. Comp. Biochem. Physiol. 71B: 669-673

Wallenborg, B., Andersson, U.-B. (1978). Immunoelectrophoretic techniques with the LKB 2117 multiphor. Application note 249, LKB-Producer AB, Bromma, Sweden, $12 \mathrm{p}$.

Manuscript first received: June 7, 1990

Revised version accepted: August 7, 1991 